\title{
EMERGING BACTERIAL RESISTANCE TO ANTIBIOTICS - FIGHTING A LOSING BATTLE !
}

As we approach the end of first decade of 21st century, it is now time to seriously reconsider the hopes and zeal that transpired in the thirties and forties of the last century with the discovery of antimicrobials like sulfa and penicillin. These magic bullets saved millions of lives from deadly infectious agents. However, by the beginning of 1960s, the enthusiasm soon faded away as many of the organisms like Staphylococcus aureus, a gram positive bacterium, became resistant to penicillin due to its capability to produce penicillin destroying enzymes called penicillinase or betalactamase. The discovery of penicllinase or betalactamse resistant penicillins like methicillin soon outwitted the smart bacteria. But this also did not last long. Staphylococcus aureus started to become resistant to methicillin. The resistance was due to a subtle change in its penicillin binding protein called PBP2a. Today, methicillin resistant $S$. aureus (MRSA) is a leading cause of hospital acquired infection in all countries of the world including Bangladesh. In a multi-center study involving four divisions of Bangladesh, the rate of isolation of MRSA from hospital patients ranged between $32-63 \% .^{1}$ The trend is alarming. There are not many affordable drugs to treat simple infections with MRSA. The emergence of antibiotic resistance is now widespread and involves both gram positive and a wide range of gram negative organisms. One example is the spread of antibiotic resistance in Salmonella typhi, a gram negative bacterium, responsible for typhoid fever in Bangladesh and in many countries of the world. Typhoid fever was treated by simple antibiotics like ampicillin, cotrimoxazole or chloramphenicol till the mid 1980s. Since then, ciprofloxacin or third generation cephalosporins have been increasingly used in the treatment of typhoid fever in Bangladesh due to development of resistance to earlier drugs. ${ }^{2}$ Since 1997, treatment failures with ciprofloxacin have slowly started to emerge in Bangladesh and other countries due to infection with nalidixic acid resistant Salmonella typhi or NARST. ${ }^{3-6}$ NARST has decreased susceptibility to ciprofloxacin. A study conducted in an urban hospital of Bangladesh noted $75 \%$ of $S$. typhi resistant to nalidixic acid vis-a-vis ciprofloxacin. ${ }^{7}$ Wonder drugs for treating typhoid have now become archaic and the list becomes ever growing. Today, many of the bacteria which were sensitive to and treatable with cephalosporins have become resistant due to production of extended spectrum beta-lactamases (ESBL). The enzyme effectively inactivates all generation of cephalosporins leaving the medical doctors with only few choices of more expensive antibiotics. A study conducted in a referral hospital of Dhaka city has noted $43.2 \%$ and $39.5 \%$ of $E$. coli and $K$. pneumoniae were of ESBL phenotypes respectively. ${ }^{8}$ The picture is similar in many other countries.

Scientists are striving to develop newer drugs to combat the emerging bacterial resistance. Exploitation of quorum sensing phenomena, use of bacteriophage and antimicrobial peptides are few examples. Many strategies have been taken to control the never ending challenges of resistant bacteria. Effective infection control and antibiotic policy are few of them. We must now cautiously prescribe antibiotics particularly, those which are considered as reserve antibiotics for multiresistant organisms. But the most important of all is not the discovery of new wonder drugs but the prudent and restrained use of antibiotics by the medical community and raising the public awareness regarding the dangers of prolific use of new and costly antibiotics. If we wish to live in a world where bacteria live subjugated to human beings, then we must realize a simple fact - the war against bacteria is far from over.

\section{References}

1. Haq JA, Rahman MM, Haque Asna SMZ, Hossain MA, Ahmed I, Haq T and Morshed MAHG. Methicillin-resistant Staphylococcus aureus in Bangladesh-a multicentre study. International Journal of Antimicrobial Agents 2005; 25: 276-277.

2. Haque Asna SMZ and Haq JA. Decrease of antibiotic resistance in Salmonella typhi isolated from patients attending hospitals of Dhaka City over a 3-year period. International Journal of Antimicrobial Agents 2000; 16: 249-251.

3. Haque Asna SMZ, Haq JA and Rahman MM. Nalidixic acid resistant Salmonella typhi with decreased susceptibility to ciprofloxacin caused treatment failure A report from Bangladesh. Japanese Journal of Infectious Diseases 2003; 56:32-33. 
4. Threlfall EJ, Ward LR, Skinner JA, et al. Ciprofloxacinresistant Salmonella typhi and treatment failure. Lancet 1999; 353: 1590-1.

5. Murdoch DA, Banatvala NA, Bone A, et al. Epidemic ciprofloxacin resistant Salmonella typhi in Tajikistan. Lancet 1998; 351: 39.

6. Wain J, Hoa NT, Chinh NT, et al. Quinolone-resistant Salmonella typhi in Vietnam: molecular basis of resistance and clinical response to treatment. Clin Infect Dis 1997; 25: 1404-10.

7. Rahman MM, Haq JA, Morshed MAHG and Rahman MA. Salmonella typhi with decreased susceptibility to ciprofloxacin - An emerging problem in Bangladesh. International Journal of Antimicrobial Agents 2005; 25: $345-346$.
8. Rahman MM, Haq JA, Hossain MA, Sultana R, Islam F, Islam AHMS. Prevalence of extended-spectrum- $\beta$ lactamase-producing Escherichia coli and Klebsiella pneumoniae in an urban hospital in Dhaka, Bangladesh, International Journal of Antimicrobial Agents 2004; 24:508-510.

\section{J. Ashraful Haq \\ Professor \\ Department of Microbiology \\ Ibrahim Medical College}

